\title{
Effects of Lean Combustion on Bioethanol-Gasoline Blends using Turbocharged Spark Ignition Engine
}

\author{
S.M. Rosdi 1,2, R Mamat $^{1}$, A Azri $^{3}$ and K. Sudhakar ${ }^{1,4}$ \\ ${ }^{1}$ College of Engineering, Universiti Malaysia Pahang, 26600 Pekan Pahang, Malaysia \\ 2Politeknik Sultan Mizan Zainal Abidin, Jabatan Kejuruteraan Mekanikal Automotif, Km 08 Jln Paka, 23000 Dungun Terengganu, Malaysia \\ ${ }^{3}$ Faculty of Mechanical and Automotive Engineering Technology, Universiti Malaysia Pahang, 26600 Pekan Pahang, Malaysia \\ ${ }^{4}$ Energy centre, Maulana Azad National Insitute of Technology, Bhopal -462003,M.P, India
}

ABSTRACT - Liquid alternative fuels have been utilised as engine fuel since the 19th century. For several alternative fuels, bioethanol is well-known as the most suited friendly, alternative-product based and renewable for use in spark-ignition (SI) engines. In addition, it is well known that bioethanol has higher evaporation of heat, research octane number and flammability of temperature; therefore, it has a greater influence on performance and lower emission. In this study, the effect of gasoline fuel RON95 (G) was blended into bioethanol fuel (E10, E20 and E30) to investigate the engine combustion, performance and emission. The engine used was $1.8 \mathrm{~L}$ Mitsubishi, four-cylinder, four-stroke, multipoint port injection and turbocharger SI. The engine speed used was $1000-3000 \mathrm{rpm}$ at $10-40 \%$ load with wide-open throttle (WOT). The results showed that bioethanol addition to gasoline increases the brake torque at a higher load. The mass fraction burn (MFB) and coefficient of variation (COV) blend fuel and main fuel are comparable to each other. The brake specific fuel consumption (BSFC) significantly increases when engine speed increases. The emission of nitrogen oxide (NOx), carbon monoxide (CO), and hydrocarbon ( $\mathrm{HC})$ emissions reduced dramatically compared to gasoline fuel. Indeed, bioethanol-gasoline fuel allows the engine utilised in low proportion to increase engine performance and lower engine emission.
ARTICLE HISTORY

Received: 29th July 2019

Revised: $15^{\text {th }}$ Aug 2021

Accepted: $7^{\text {th }}$ Sept 2021

\section{KEYWORDS}

Bioethanol;

Performance;

Emission;

Lean mixture

\section{NOMENCLATURE}

$\begin{array}{llll}\text { RON } & \text { research octane number } & \mathrm{CO}_{2} & \text { carbon dioxide } \\ \text { PI } & \text { port injection } & \mathrm{CO} & \begin{array}{l}\text { carbon monoxide } \\ \text { nitrogen oxide }\end{array} \\ \text { BMEP } & \text { brake mean effective pressure } & \mathrm{NOx} & \text { hydrocarbon } \\ \text { VE } & \text { volumetric efficiency } & \mathrm{HC} & \text { radian per minute } \\ \text { BSFC } & \text { brake specific fuel consumption } & \mathrm{RPM} & \text { engine control unit } \\ \text { SOHC } & \text { single overhead cam } & \mathrm{ECU} & \text { greenhouse gas } \\ \text { MPFI } & \text { multiport fuel injection } & \mathrm{GHG} & \text { spark ignition } \\ \text { PPM } & \text { particle per million } & \mathrm{SI} & \text { brake power } \\ \mathrm{CV} & \text { calorific value } & \mathrm{Bp} & \text { brake torque } \\ \mathrm{ICE} & \text { internal combustion engine } & \mathrm{BT} & \\ \mathrm{H} 2 \mathrm{O} & \text { water } & & \end{array}$

\section{INTRODUCTION}

Today, growing emission is one of the significant problems in developed countries. The emissions from the vehicles have the main role in inducing greenhouse gas $(\mathrm{GHG})$ and pollution. The design of the vehicle to follow legal regulations is not sufficient; thus, it necessary to use alternative fuel as modern energy. It is important that alternative fuel is produced from renewable sources and use directly without requiring any major engine modification. Alcohols fuel have been used for the engine since the $19^{\text {th }}$ century to run the engine. Bioethanol is one of among alternative fuels that are well known suitable for the spark ignition (SI) engine. The properties of bioethanol most attractive for use in SI engines are, it can be produced from renewable energy sources such as barley, corn, sugar, cane or waste biomass [1]-[10]. Iodice and Senatore [11] described that in their study on National Interest Priority Sites (NIPS) with two categories (road traffic and industry power plans). From the anthropogenic activities, the carbon monoxide, nitrogen dioxide, particulate matter and volatile organic compounds are $83 \%, 28 \%, 39 \%$ and $41 \%$, respectively.

The range of operating parameters for spark-ignition engines is limited by cyclic fluctuation, particularly in lean and highly diluted circumstances. Pressure parameters, combustion-related parameters, and flame-front related parameters can all be used to characterise cyclic combustion fluctuations. The cyclic variability in indicated work per cycle is defined by the coefficient of variation (COV) in Indicated Mean Effective Pressure (IMEP). Zhao et al. [12] described that the 
engine cylinder pressure and heat release increase when the engine run under lean combustion. It was shown that higher combustion efficiency and acceptable COV could be obtained when excess ratios are 1.2 and 1.3. While Mass Fraction Burned (MFB) chart illustrate how in-cylinder combustion progresses as a function of crank angle. The rate of combustion within a cylinder has a significant impact on the engine's thermal efficiency, peak cycle temperature and pressure, and exhaust emissions. The burn crank angles at which the MFB achieves a given value are commonly used to calculate this combustion rate. On the basis of cumulative heat release, the mass fraction burned functions are derived in Eq. (1). CA05, CA50, and CA95 are the locations of characteristic points characterising combustion advance, i.e. $5 \%, 50 \%$, and $95 \%$ MFB, as read from MFB curves. Only the MFB50 was used in this study. According to MFB graphs by Ilhak et al. [13], the combustion times of gasoline and ethanol at $25 \%$ load are nearly identical; however, ethanol's combustion time at $50 \%$ load is greater than gasoline. Furthermore, ethanol has a CA50 value that is higher than gasoline at 50\% load. In this situation, ethanol combustion, conversion to heat, and pressure effects take longer, resulting in higher ethanol variation values from cycle to cycle.

$$
M F B=\frac{\sum_{0}^{i} \Delta P c}{\sum_{0}^{N} \Delta P c}
$$

where, $O$ is the start of combustion and $N$ is the end of combustion. The mass fraction consumed after the considered $i$-th interval can be determined by assuming that the pressure rise $\triangle P C$ is proportional to the heat contributed to the incylinder medium during the crank angle period.

Currently, bioethanol is still used in light SI engines with gasoline fuel at low proportions. It allows the engine use of bioethanol without modification. This method was recommended and will be improved on performance, cold start and anti-knock. In addition, another advantage of the bioethanol flame is colourless in the natural burning process [2], [14]. Since the lower energy content of bioethanol is lower than gasoline, it needed to increase the mass of fuel during spray to achieve the same output power [15]. Bioethanol contains an oxygen atom, and it is miscible with $\mathrm{H}_{2} \mathrm{O}$ in all mixtures. Then water contains in bioethanol contribute to the corrosion problem on the mechanical part. In order to avoid this problem on the fuel delivery system, some materials, especially copper, brass and aluminium, are not used. Therefore, among the material that can use is fluorocarbon rubber or stainless steel.

Many researchers have investigated the effects of bioethanol-gasoline fuel blends on engine performance and emission. Feng et al. [16] and Gravalos [17] mentioned that the difference of performance and emission alcohol fuel to reference fuel is due to the higher fuel vaporisation and combustible charge formation at high engine speeds and higher oxygen content. Deng et al. [18] used hydrous ethanol to blend gasoline in $10 \%$ and $20 \%$ proportions. They ran the engine at 1500-5000 rpm and used full load conditions. The blend of 10\% hydrous ethanol-gasoline (E10W) exhibit enhanced performance, while NOx, CO and HC significantly decrease. Yusoff et al. [19] investigated the effect of ethanolisobutanol-gasoline blends fuels on engine performance and emission at 1000-5000 rpm. The results showed that the fuel blends have slightly higher torque compared to gasoline, where E10, E20, iB10, iB20, E10iB10 recorded at 2.33, 3.88, 2.56, 3.06, 1.06 and 3.77\%, respectively. Meanwhile, higher blends, i.e. E20, iB20, and E10iB10, give higher brake power compared to gasoline, with an average increase of $2.6,2.57$ and $2.22 \%$, respectively. In terms of emissions, they concluded the $\mathrm{E} 20$ and $\mathrm{E} 10 \mathrm{iB} 10$ have the lowest $\mathrm{CO}$ and $\mathrm{HC}$, respectively. However, all the tested fuel blends showed higher $\mathrm{CO}_{2}$ at an average of $10.67 \%$ compared to gasoline. The NOx emission rises dramatically when the engine uses higher speed and torque but blends fuel shows lower than gasoline. Basically, NOx formation is through three pathways, (1) fuelnitrogen conversion, (2) Zeldovich thermal activation, and (3) fuel-rich prompt formation [20], [21]. The two-wheel vehicle shows the effect of fuel consumption and emission using three ways catalyst and belongs to Euro 3 legislation exhaust emission. As a result, the statistical obtained the medium size motorcycle under real driving behaviour [22].

He et al. [1] concluded that the fuel comprising $30 \%$ of ethanol by volume induces lower HC, CO, and NOx emission at idle, but unburned ethanol introduces increased emission. The equivalent ratio and mass of ethanol play a significant role in the combustion, as mentioned by $\mathrm{Wu}$ et al. [23]. The effect of using gasoline-ethanol blends with a different percentage on performance and emission SI engine was investigated by Al-Hasan [2]. They mentioned that the blends of ethanol to gasoline increase the volumetric efficiency, brake power, brake thermal and fuel consumption, while it decreases the brake specific fuel consumption and equivalence air-fuel ratio. The concentration of $\mathrm{CO}$ and $\mathrm{HC}$ emission decreased, whereas the $\mathrm{CO}_{2}$ increased dramatically. Yucesu et al. [24] used gasoline (E0) as base fuel and gasolineethanol blends (E10, E20, E40 and E60) into engine one cylinder, four-stroke, spark ignition and adjustable compression ratio. As a result, blends fuel slightly increased the brake torque with increasing compression ratio without detonation and reduced $\mathrm{HC}$ and $\mathrm{CO}$ emission. The higher surface to volume ratio and higher compression ratio is due to higher $\mathrm{HC}$ formation [25] [26].

From literature, bioethanol-gasoline can be used effectively as blends fuel in a SI engine. Bioethanol has a higher research octane number (RON) and the high evaporation of heat and contains over $30 \%$ oxygen by weight. If the amount of bioethanol increased in blends, the heating value of fuel blends decreases. Thus, the lower heating value allows for increasing the fuel mass during the intake suction process. Among the influence on engine performance, the timing of ignition, air-fuel ratio, heat of vaporisation, compression ratio and flame speed are considered. This study evaluated engine efficiency and emission on lean conditions with the presence of bioethanol in gasoline as a low proportion. The test was conducted in low load and low engine speed as used in the urban area. In this study, the effects of bioethanolgasoline blends on engine performance and emission was investigated using a turbocharged light SI engine. The engine 
speed was used at 1000-3000 rpm, and fuel blends were set at 10\%, 20\% and 30\% (E10, E20 and E30) with gasoline (G) as reference. The engine load was applied at 10-40\% wide open throttle (WOT).

\section{EXPERIMENTAL APPARATUS AND PROCEDURE}

\section{Experimental Apparatus}

The set-up of experimental consists of a Mitsubishi turbocharged spark ignition (SI) engine, four-stroke, four-cylinder, and multipoint port injection. It was coupled with a $100 \mathrm{~kW}$ eddy current dynamometer to measure engine performance. A strain gauge based load cell attached to the dynamometer was used for load measurement. The schematic view of the experimental setup is shown in Figure 1. The general specifications of the test engine are given in Table 1. A fuel flow meter (AIC-1204 HR 2000 model) was used to measure air delivery into the engine cylinder. A gas analyser (Kane Autoplus 5-2) was used to analyse the engine emission constituents, for example, NOx, CO, and HC and air-fuel proportions. All the devices were calibrated and tested regularly. The accuracies of the devices and uncertainties in the calculated results are shown in Table 2.

1.Dynamometer 2.Exhaust gas analyser

3.In-cylinder pressure and encoder

4.Cooling temperature

5.ECU

6.PICO data $\log$ for alltemperature

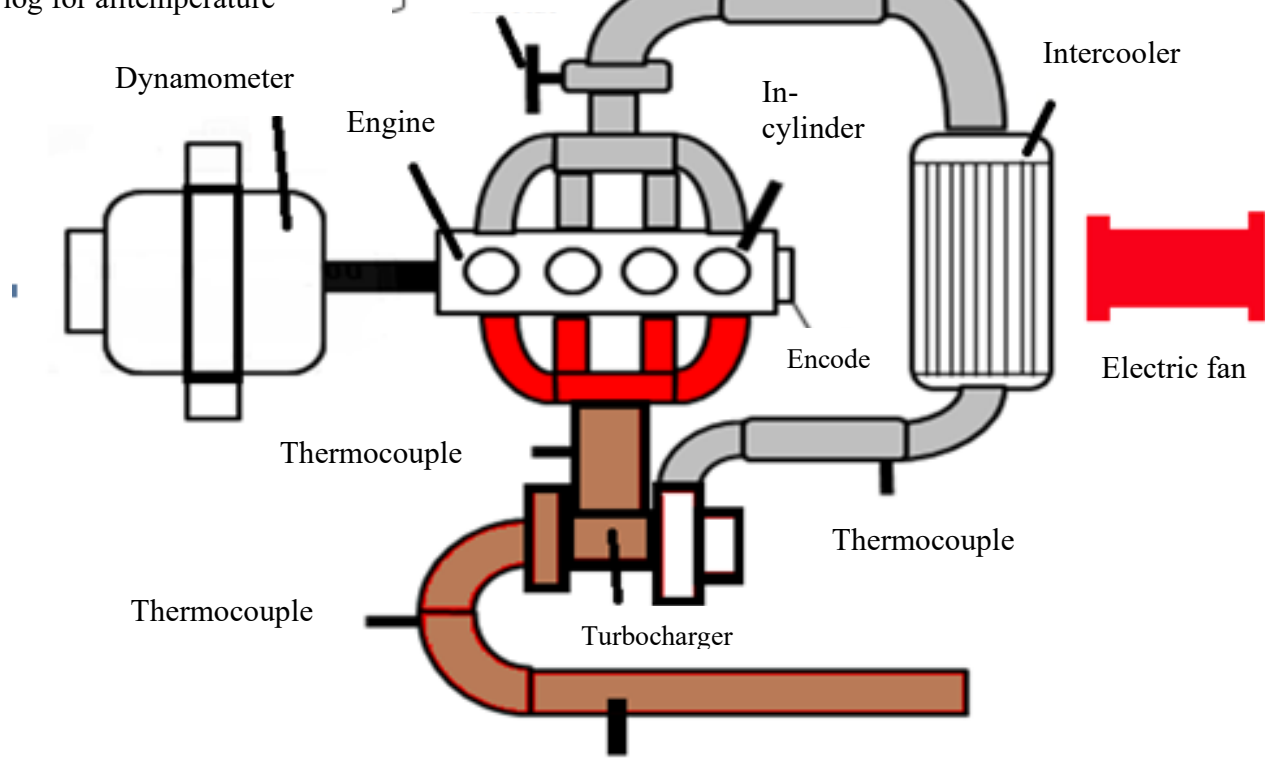

Exhaust gas analyser

Figure 1. Schematic diagram engine test rig.

Table 1. Specifications of SOHC 16 V MPI Mitsubishi engine.

\begin{tabular}{lclc}
\hline Item & Specification & Item & Specification \\
\hline Number of cylinders & 4 straight line & Maximum torque & $220 @ 3000(\mathrm{Nm})$ \\
Displacement & $1.8(\mathrm{~L})$ & Intake valve open & 261 degree BTDC \\
Chambers combustion type & Pentroof Type & Intake valve close & 209 degree ATDC \\
Cylinder bore & $81(\mathrm{~mm})$ & Intake valve lift & $9.7 \mathrm{~mm}$ \\
Piston stroke & $89(\mathrm{~mm})$ & Exhaust valve open & 257 degree BTDC \\
Compression ratio & $9.5: 1$ & Exhaust valve close & 204 degree ATDC \\
Maximum output & $118 @ 6000(\mathrm{~kW})$ & Exhaust Valve lift & $9.5 \mathrm{~mm}$ \\
\hline
\end{tabular}

Table 2. The accuracies of the devices and uncertainties in the calculated result by manufacturer.

\begin{tabular}{lcc}
\hline Measurement & Range & Accuracy \\
\hline In-cylinder pressure & $40-80 \mathrm{Bar}$ & $\pm 0.4 \%$ \\
Fuel consumption & $1.2-130 \mathrm{~kg} / \mathrm{h}$ & $\pm 0.1 \%$ \\
Temperatures & $80-90^{\circ} \mathrm{C}$ & $\pm 1{ }^{\circ} \mathrm{C}$ \\
Air delivery & $0.5-100 \mathrm{slpm}$ & $\pm 0.8 \%$ \\
\hline
\end{tabular}




\section{Test Cases Examined}

All tests were conducted at three different engine speed (1000, 2000 and $3000 \mathrm{rpm})$ at 10-40\% wide open throttle after engine warm-up. At each engine speed, three different fuels (E10, E20 and E30) were compared to gasoline. The properties of the fuels are shown in Table 3, where bioethanol has a purity of $99.5 \%$. The test was carried out for brake torque, engine speed, fuel consumption, air delivery into the cylinder, spark timing, and emission (CO, HC and NOx). For each experiment, three times was replication to average data. The condition of the engine was allowed to reach a stable then measurements were verified. Then, for each operating condition, the access of air-fuel ratio was maintained during all experiments. Table 4 shows the specification of the exhaust gas analyser using for this study.

Table 3. Properties of gasoline and bioethanol [27] [28][29].

\begin{tabular}{lcccccc}
\hline Properties & Test Standard & Bioethanol & Gasoline & E10 & E20 & E30 \\
\hline Stoichiometry (weight) & Calculated & 9 & 14.7 & 13.5 & 12.6 & 11.7 \\
Octane Number & ASTM D2699 & 106.6 & 95 & 98.1 & 100.7 & 102.4 \\
LHV $(\mathrm{MJ} / \mathrm{kg})$ & ASTM D240 & 26.9 & 44 & 41 & 39.4 & 37.8 \\
Density $\left(\mathrm{kg} / \mathrm{m}^{3}\right)$ & ASTM D4052 & $785[30]$ & 737 & 761 & 765 & 768 \\
\hline
\end{tabular}

Table 4. Specification of exhaust gas analyser.

\begin{tabular}{lc}
\hline Description & Specification \\
\hline Model & Autoplus $5-2$ \\
Measurement principle & 6 volt DC \\
Power supply & Flow rate (Minimum $1 /$ min, normal $2.51 / \mathrm{min})$ \\
Flue temp & $0-1200{ }^{\circ} \mathrm{C}$ with suitable probe \\
Inlet temp & $0-50{ }^{\circ} \mathrm{C}$ \\
Oxygen $\left(\mathrm{O}_{2}\right)$ & Range $0-21 \% @ \pm 5 \%$ accuracy \\
Carbon monoxide $(\mathrm{CO})$ & Range $0-10 \% @ \pm 5 \%$ accuracy \\
Carbon dioxide $\left(\mathrm{CO}_{2}\right)$ & Range $0-16 \% @ \pm 5 \%$ accuracy \\
Nitrogen oxides $(\mathrm{NOx})$ & Range $0-5000 \mathrm{ppm} @ \pm 5 \%$ accuracy \\
\hline
\end{tabular}

\section{RESULTS AND DISCUSSION}

\section{Mass Fraction Burn (MFB) and Coefficient of Variation IMEP (COVimep)}

Figure 2 shows the location mass fraction burn (MFB) or maximum heat release rate (MHRR) for G, E10, E20 and E30 using engine speed at 1000-3000 rpm. MFB advance when fuel blends increase, engine speed and engine load increase. The advancing of MFB due to fuel blends show faster flame speed during lean combustion. Elik et al. [31] described that MFB is a process of chemical energy released as a function of crank angle. Iodice et al.[32] pointed that faster flame speed by blends ethanol induces the increase of brake power and increased volumetric efficiency.

While the COV imep shows stability in engine combustion, the graph of COV imep shows an increasing trend when the engine uses gasoline-bioethanol blends fuel compared to gasoline. It means that the engine is slightly rough when using ethanol-gasoline blends. The range of COVimep in this study is 3-7\%. Then the E30 shows higher COV compared to other fuels. The COV increase due to occurring lean combustion of blended fuels and occurring misfire in the engine cylinder. Park et al. [33] described that an increased air access ratio (lean) causes an increase in the cycle of variation and results in the deterioration of thermal efficiency. Heywood [34] mentioned that when the engine is below $10 \%$ of $\mathrm{COV}$, the engine run smooth and stable. Wang et al. [35] also pointed out that the engine is stable if the COV range is below $10 \%$.

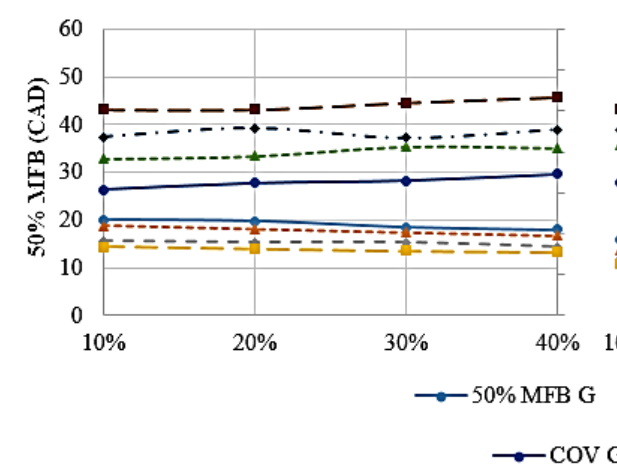

(a)

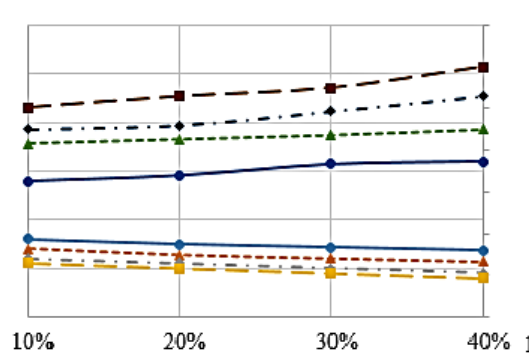

$40 \% \quad 10 \%$

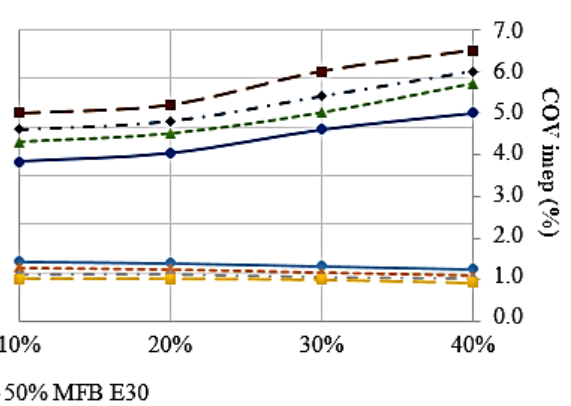

COV E30

(c)

Figure 2. The location MFB 50\% and COV as a function using engine load at $10-40 \%$.

\section{Brake Torque}

Figure 3 shows the brake torque as a function engine load at 10-40\%. The brake torque for engine speed at $1000 \mathrm{rpm}$ was recorded around 52-62 Nm, and Gasoline (G) is higher than all fuel. At $2000 \mathrm{rpm}$ was illustrated that the brake torque 
for gasoline and bioethanol-gasoline blends is comparable to each other at around 45-82 $\mathrm{Nm}$ and close with each other. The brake torque at engine speed $3000 \mathrm{rpm}$ early start with $40 \mathrm{Nm}$. The trend was showed that bioethanol-gasoline blends increase compared to gasoline. The brake torque for blends bioethanol is higher than gasoline and was recorded at 105 $\mathrm{Nm}$. Below are several reasons that can be related to brake torque bioethanol, which is higher than gasoline. Although bioethanol has lower heating value, the bioethanol has oxygen in the atom allows more to complete combustion, thereby increasing the torque and power. In addition, a larger spray fuel for some volume was injected into the cylinder due to the higher density of bioethanol [19]. The hydroxyl radical occurring due to complete combustion induces advanced flame speed [36], and subsequent heat release occurs early. The average raising in brake torque for bioethanol fuel blends compared to gasoline was about $1 \%, 1.8 \%$ and $2.3 \%$ for E10, E20 and E30, respectively.

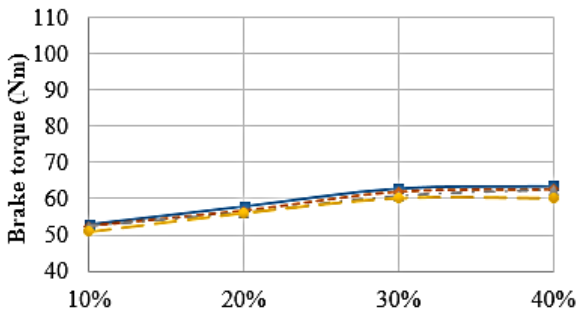

(a)

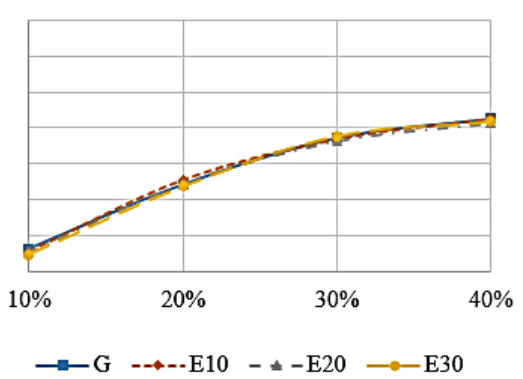

(b)

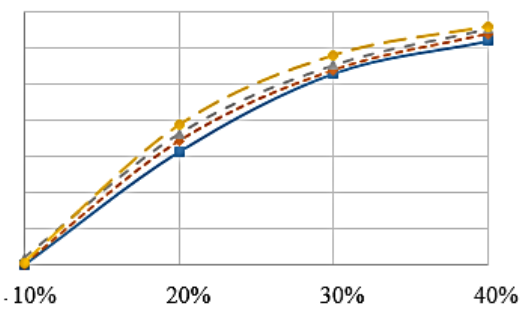

(c)

Figure 3. Brake torque as a function engine load (a) $1000 \mathrm{rpm}$, (b) $2000 \mathrm{rpm}$ and (c) $3000 \mathrm{rpm}$.

\section{Brake Specific Fuel Consumption}

Figure 4 illustrates the brake specific fuel consumption (BSFC) of the engine using G, E10, E20 and E30 fuels with respect to engine loads at 10-40\% and engine speed 1000-3000 rpm. As shown in graph BSFC for $1000 \mathrm{rpm}$, low load shows higher BSFC than higher load due to higher heat loss. It was occurred due to efficiency air suction at low load better than higher load. In addition, the BSFC is slight far from each other at the low load. It's recorded at a range of 560$750 \mathrm{~g} / \mathrm{kW}$.h. At higher load, the BSFC reduced due to choking at the throttle. At $2000 \mathrm{rpm}$, the BSFC shows an increased average of $20 \%$ for lower load compared to $1000 \mathrm{rpm}$. The range BSFC of $2000 \mathrm{rpm}$ is $290-620 \mathrm{~g} / \mathrm{kW}$.h. At a higher load, it was reduced at $8 \%$ compared to $1000 \mathrm{rpm}$. BSFC at $3000 \mathrm{rpm}$ recorded at $480-380 \mathrm{~g} / \mathrm{kW}$.h at low load. When higher load, it showed the lowest decrease at 350-390 g/kW.h. All BSFC shows that increasing trend when increased engine speed and engine load.

The lower heating value of bioethanol-gasoline fuel causes raising BSFC of the engine when it is used without any alter of the engine. The increment significantly depends on the percentage of bioethanol. Najafi et al. [30] mentioned that the BSFC of bioethanol fuel is higher than that of gasoline owing to its lower heating value, higher viscosity and density. The viscosity obstructs the vaporisation and atomisation and deteriorates the combustion, leading to an increased BSFC [37]. Hasan et al. [38] mentioned that using biofuel blend with gasoline increase BSFC due to higher density, then it contributes to increasing brake torque. The decrease of BSFC at higher load and higher engine speed is due to pumping losses. It contributes to occurring slow motion of air intake in the cylinder compared to lower load and lower engine speed due to some of the air sent back to the intake system [39].

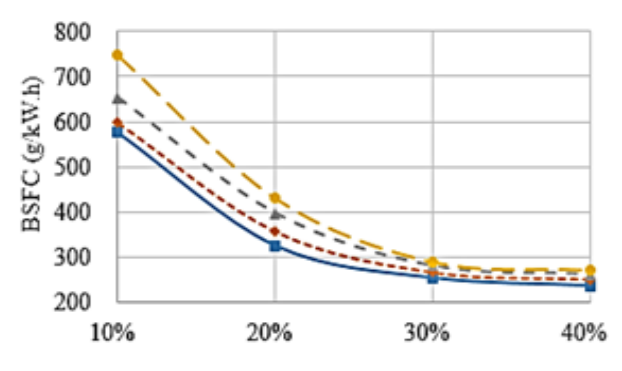

(a)

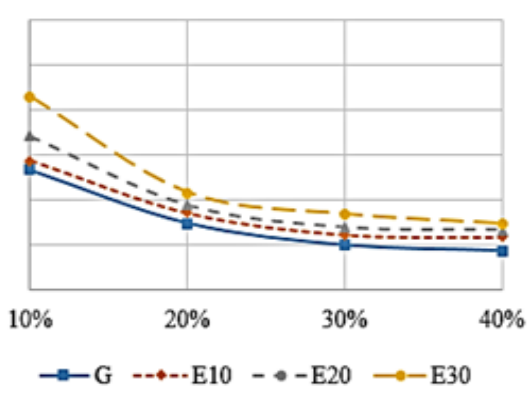

(b)

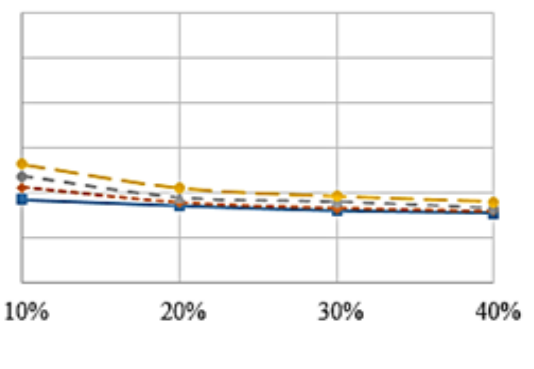

(c)

Figure 4. Brake specific fuel consumption as a function engine load at (a) $1000 \mathrm{rpm}$, (b) $2000 \mathrm{rpm}$ and (c) $3000 \mathrm{rpm}$.

\section{Carbon monoxide}

Figure 5 illustrates the influence of bioethanol-gasoline and gasoline on carbon monoxide (CO) emissions as a function engine load at $10-40 \%$. The $\mathrm{CO}$ emission is a product of incomplete combustion due to an insufficient amount of air intake mixture in the combustion. The formation of $\mathrm{CO}$ emissions significantly depends on the engine operation and the air-fuel mixture. At $1000 \mathrm{rpm}$, the $\mathrm{CO}$ emission reduces due to complete combustion when the load increases. Thus, CO emission averagely increase $20 \%$ at $2000 \mathrm{rpm}$. At $3000 \mathrm{rpm}$, the $\mathrm{CO}$ emission averagely increased by $6 \%$ compared to $2000 \mathrm{rpm}$. Gasoline fuel showed that CO emission was higher than compared to all bioethanol-gasoline fuel 
blends. But all $\mathrm{CO}$ emission shows a decreasing trend when increases engine load. The reduction of $\mathrm{CO}$ emission due to the lean mixture effect is defined as enhancing the oxygen in the fuel mixture, which improves combustion efficiency in the engine cylinder [40][41]. In addition, it decreases with decreasing the temperature of combustion [34][25]. Besides that, bioethanol has a higher flame speed compared to gasoline fuel will assist in completing combustion, which induces lower CO emission [42][25]. The results were also concordant with findings of the previous researcher, which utilised bioethanol and gasoline blends [43][44].

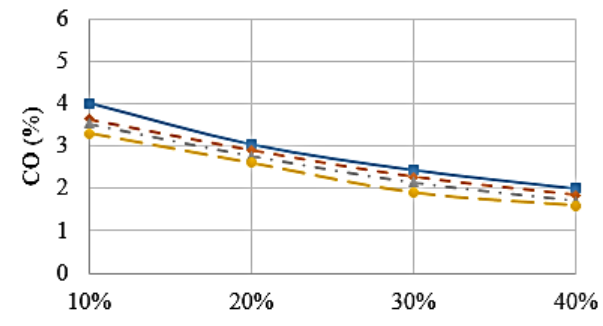

(a)

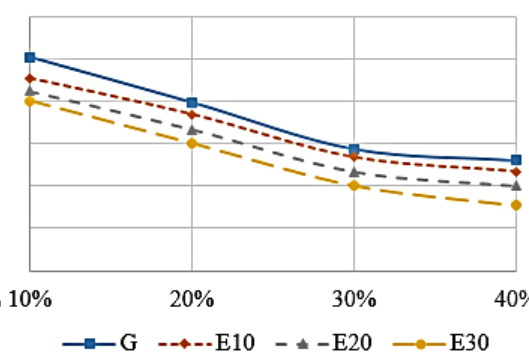

(b)

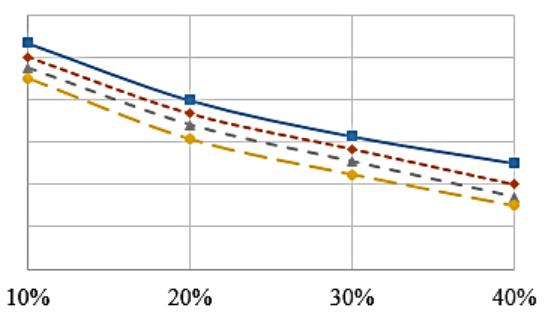

(c)

Figure 5. Carbon monoxide as a function engine load at (a) $1000 \mathrm{rpm}$, (b) $2000 \mathrm{rpm}$ and (c) $3000 \mathrm{rpm}$.

\section{Hydrocarbon}

Figure 6 illustrates the hydrocarbon (HC) emissions as a function to $10-40 \%$ using engine load at 1000-3000 rpm. The $\mathrm{HC}$ emission significantly reduces when the engine uses bioethanol-gasoline fuel blends compared to gasoline and closely with each other. At $1000 \mathrm{rpm}$, it reveals the range of $\mathrm{HC}$ emission is 185-285 (ppm). At $2000 \mathrm{rpm}$, it was decreased averagely by $7 \%$ compared to $1000 \mathrm{rpm}$. HC emission for $3000 \mathrm{rpm}$ reduces averagely at $1.7 \%$ compared to $2000 \mathrm{rpm}$. The heat of air suction from turbocharger boost induces complete combustion, thus the oxygen enrichment and leaning effect. It is determined that raising the bioethanol in gasoline improves the turbulence intensity during combustions. In addition, bioethanol blends provide extra complete combustion and induce a reduction in HC formation. Besides, the formation of $\mathrm{HC}$ emission is closely related to engine design and variable engine operation. Then, the lowest cylinder combustion temperature resulted in incomplete combustion of the residual fuel [25]. Results are also concordant with Najafi et al. [30]. They mentioned that oxygen content in bioethanol is shown to pre-oxidise the air-fuel mixture leading to reduce $\mathrm{HC}$ emissions.

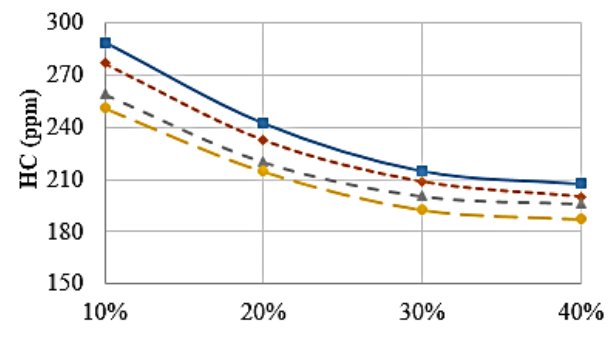

(a)

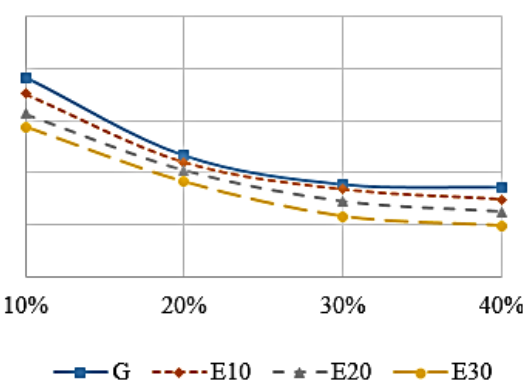

(b)

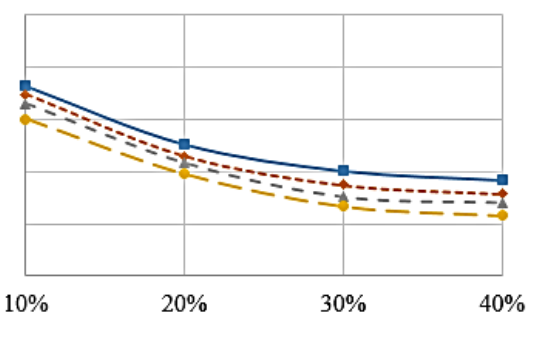

(c)

Figure 6. Hydrocarbon as a function engine load (a) $1000 \mathrm{rpm}$, (b) $2000 \mathrm{rpm}$ and (c) $3000 \mathrm{rpm}$.

\section{Nitrogen oxide}

The formation of nitrogen oxide (NOx) emission significantly depends on the peak temperatures during combustion. It formed above the temperature of $1500{ }^{\circ} \mathrm{C}$. Figure 7 shows the NOx emission as a function of $10-40 \%$ engine load. NOx emission for $1000 \mathrm{rpm}$ was recorded at $325-510 \mathrm{ppm}$. At $2000 \mathrm{rpm}$, it increased to $350-850 \mathrm{ppm}$. NOx emission at 3000 rpm was recorded at 650-1050 ppm range. When higher load, the graph close for each other due to complete combustion. All the NOx emission graphs showed an increasing trend when the engine load increased. NOx for gasoline was showed higher than all bioethanol-gasoline blends. The temperature of combustion is higher, and local oxygen concentration in the peak temperature zone was favourable to NOx emission formation in gasoline fuel. But, NOx emission reduces as a result of adding bioethanol to gasoline fuel. It was concordant with Li et al. [21] and concluded that use alcohol in their study contributes cooling effect in the cylinder combustion. In addition, the high latent heat of vaporisation of bioethanol lowers the flame temperature and induces NOX lower emission. So, NOx emission may change depending on the percentage of bioethanol blends in gasoline. Oxygen concentration and combustion temperature, and time are the main parameters affecting the NOx emission [45]. 


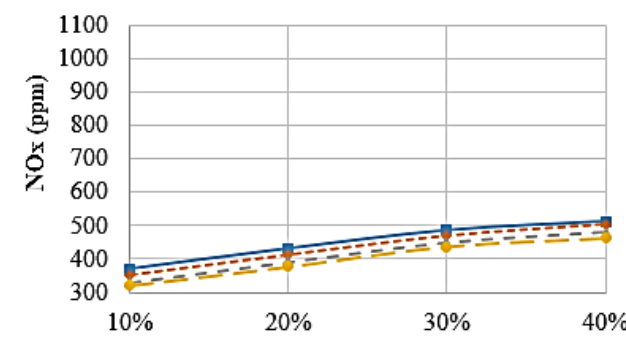

(a)

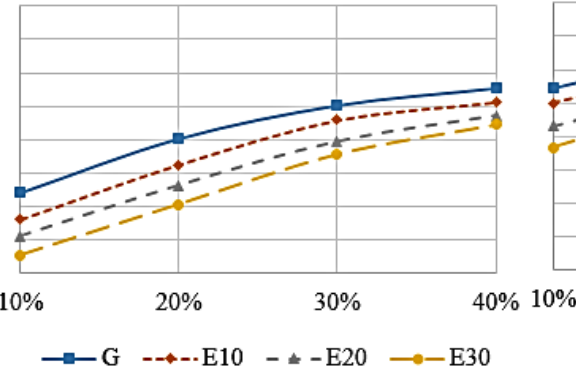

(b)

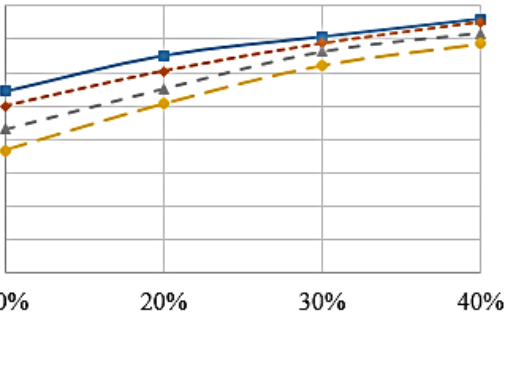

(c)

Figure 7. Nitrogen dioxide as a function engine load (a) $1000 \mathrm{rpm}$, (b) $2000 \mathrm{rpm}$ and (c) $3000 \mathrm{rpm}$.

\section{CONCLUSION}

In this study, the effects of gasoline $(\mathrm{G})$ and bioethanol-gasoline blends (E10, E20 and E30) on engine performance and emission were investigated in a turbocharged SI engine, four-stroke, four-cylinder at WOT.

i. It was demonstrated that bioethanol-gasoline fuel mixes provide comparable engine performance and reduced emissions without detonating the engine.

ii. While COV showed an increasing trend, that means slight vibration occurred during combustion when using ethanol blend compared to gasoline. The lean combustion also promotes MFB advance for 50\% duration compared to gasoline. It shows that when fuel blends increase, a slightly advanced combustion occur but lower performance due to lower heating value.

iii. The research presented here has shown that two-component blends of gasoline and ethanol may be produced and used in existing gasoline automobiles. Such gasoline-ethanol mixes have constant volumetric energy content, constant octane values, and near-constant vaporisation enthalpies when blended with constant stoichiometry. The energy content in bioethanol-gasoline fuel is lower than gasoline caused the BSFC of the engine to increase and depends on the percentage of blends.

iv. An effect of lean combustion and complete combustion was showed a reduction in $\mathrm{HC}$ and $\mathrm{CO}$ emission due to oxygenated fuel by the bioethanol. Because to lower pumping and heat loss, as well as more thorough combustion, stratified lean burn characteristics enhanced engine fuel conversion efficiency.

v. The load, combustion efficiency, and net indicated efficiency of gasoline-ethanol were all similar. Because of the greater hydrocarbon ratio, total $\mathrm{CO}$ and $\mathrm{HC}$ emissions from ethanol blends were lower than gasoline. The peak bulk temperatures produced by the combustion of ethanol blends were lower than those produced by gasoline, resulting in a lower NOx emission index, which also accounted for the higher ethanol flow rates into the engine.

\section{ACKNOWLEDGEMENT}

The financial support of Universiti Malaysia Pahang - Malaysia (RDU172204 and GRS150369) is greatly acknowledged.

\section{REFERENCES}

[1] B.-Q. He, J.-M. Hao, X.-G. Yan, and J.-H. Xiao, "A study on emission characteristics of an EFI engine with ethanol blended gasoline fuels," Atmos. Environ., vol. 37, no. 7, pp. 949-957, Mar. 2003, doi: 10.1016/S1352-2310(02)00973-1.

[2] M. Al-Hasan, "Effect of ethanol-unleaded gasoline blends on engine performance and exhaust emission," Energy Convers. Manag., vol. 44, no. 9, pp. 1547-1561, Jun. 2003, doi: 10.1016/S0196-8904(02)00166-8.

[3] H. Bayraktar, "Experimental and theoretical investigation of using gasoline-ethanol blends in spark-ignition engines," Renew. Energy, vol. 30, no. 11, pp. 1733-1747, Sep. 2005, doi: 10.1016/j.renene.2005.01.006.

[4] S. Prasad, A. Singh, and H. C. Joshi, "Ethanol as an alternative fuel from agricultural, industrial and urban residues," Resour. Conserv. Recycl., vol. 50, no. 1, pp. 1-39, 2007, doi: 10.1016/j.resconrec.2006.05.007.

[5] I. Çelikten, "The effect of biodiesel, ethanol and diesel fuel blends on the performance and exhaust emissions in a DI diesel engine," Gazi Univ. J. Sci., vol. 24, no. 2, pp. 341-346, 2011.

[6] M. S. Rocha and J. R. Simões-Moreira, "A simple impedance method for determining ethanol and regular gasoline mixtures mass contents," Fuel, vol. 84, no. 4, pp. 447-452, 2005, doi: 10.1016/j.fuel.2004.09.011.

[7] F. Manzini, "Inserting renewable fuels and technologies for transport in Mexico City Metropolitan Area," Int. J. Hydrogen Energy, vol. 31, no. 3, pp. 327-335, 2006, doi: 10.1016/j.ijhydene.2005.06.024.

[8] H. Kuszewski, "Experimental investigation of the effect of ambient gas temperature on the autoignition properties of ethanoldiesel fuel blends," fuel, vol. 214, no. November 2017, pp. 26-38, 2018, doi: 10.1016/j.fuel.2017.10.123.

[9] Y. Qian, G. Liu, J. Guo, Y. Zhang, L. Zhu, and X. Lu, "Engine performance and octane on demand studies of a dual fuel spark ignition engine with ethanol/gasoline surrogates as fuel," Energy Convers. Manag., vol. 183, no. January, pp. 296-306, 2019, doi: 10.1016/j.enconman.2019.01.011.

[10] Z. Ran, D. Hariharan, B. Lawler, and S. Mamalis, "Experimental study of lean spark ignition combustion using gasoline, ethanol, natural gas, and syngas," Fuel, vol. 235, no. May 2018, pp. 530-537, 2019, doi: 10.1016/j.fuel.2018.08.054. 
[11] P. Iodice and A. Senatore, "Air pollution and air quality state in an Italian National Interest Priority Site. Part 1: The emission inventory," Energy Procedia, vol. 81, pp. 628-636, 2015, doi: 10.1016/j.egypro.2015.12.047.

[12] L. Zhao, X. Wang, D. Wang, and X. Su, "Investigation of the effects of lean mixtures on combustion and particulate emissions in a DISI engine fueled with bioethanol-gasoline blends," Fuel, vol. 260, no. March 2019, p. 116096, 2020, doi: 10.1016/j.fuel.2019.116096.

[13] M. İ. İlhak, R. Doğan, S. O. Akansu, and N. Kahraman, "Experimental study on an SI engine fueled by gasoline, ethanol and acetylene at partial loads," Fuel, vol. 261, no. October 2019, 2020, doi: 10.1016/j.fuel.2019.116148.

[14] T. Topgül, H. S. Yücesu, C. Çinar, and A. Koca, "The effects of ethanol-unleaded gasoline blends and ignition timing on engine performance and exhaust emissions," Renew. Energy, vol. 31, no. 15, pp. 2534-2542, 2006, doi: 10.1016/j.renene.2006.01.004.

[15] C. Wang, S. Zeraati-Rezaei, L. Xiang, and H. Xu, "Ethanol blends in spark ignition engines: RON, octane-added value, cooling effect, compression ratio, and potential engine efficiency gain," Appl. Energy, vol. 191, pp. 603-619, 2017, doi: 10.1016/j.apenergy.2017.01.081.

[16] R. Feng et al., "Combustion and emissions study on motorcycle engine fueled with butanol-gasoline blend," Renew. Energy, vol. 81, pp. 113-122, Sep. 2015, doi: 10.1016/j.renene.2015.03.025.

[17] I. Gravalos et al., "Detection of fuel type on a spark ignition engine from engine vibration behaviour," Appl. Therm. Eng., vol. 54, no. 1, pp. 171-175, May 2013, doi: 10.1016/j.applthermaleng.2013.02.003.

[18] X. Deng, et al., "Exhaust noise, performance and emission characteristics of spark ignition engine fuelled with pure gasoline and hydrous ethanol gasoline blends," Case Stud. Therm. Eng., vol. 12, no. February, pp. 55-63, 2018, doi: 10.1016/j.csite.2018.02.004.

[19] M. N. A. M. Yusoff et al., "Comparative assessment of ethanol and isobutanol addition in gasoline on engine performance and exhaust emissions," J. Clean. Prod., vol. 190, pp. 483-495, 2018, doi: 10.1016/j.jclepro.2018.04.183.

[20] B. M. Masum et al., "Effect of ethanol-gasoline blend on NOx emission in SI engine," Renew. Sustain. Energy Rev., vol. 24, pp. 209-222, Aug. 2013, doi: 10.1016/j.rser.2013.03.046.

[21] Y. Li et al., "Experimental comparative study on combustion, performance and emissions characteristics of methanol, ethanol and butanol in a spark ignition engine," Appl. Therm. Eng., vol. 115, pp. 53-63, 2017, doi: 10.1016/j.applthermaleng.2016.12.037.

[22] P. Iodice and A. Senatore, "New research assessing the effect of engine operating conditions on regulated emissions of a 4stroke motorcycle by test bench measurements," Environ. Impact Assess. Rev., vol. 61, pp. 61-67, 2016, doi: 10.1016/j.eiar.2016.07.004.

[23] C. W. Wu, R. H. Chen, J. Y. Pu, and T. H. Lin, "The influence of air-fuel ratio on engine performance and pollutant emission of an SI engine using ethanol-gasoline-blended fuels," Atmos. Environ., vol. 38, no. 40 SPEC.ISS., pp. 7093-7100, 2004, doi: 10.1016/j.atmosenv.2004.01.058.

[24] H. S. Yücesu, T. Topgül, C. Çinar, and M. Okur, "Effect of ethanol-gasoline blends on engine performance and exhaust emissions in different compression ratios," Appl. Therm. Eng., vol. 26, no. 17-18, pp. 2272-2278, Dec. 2006, doi: 10.1016/j.applthermaleng.2006.03.006.

[25] M. Koç, Y. Sekmen, T. Topgül, and H. S. Yücesu, "The effects of ethanol-unleaded gasoline blends on engine performance and exhaust emissions in a spark-ignition engine," Renew. Energy, vol. 34, no. 10, pp. 2101-2106, Oct. 2009, doi: 10.1016/j.renene.2009.01.018.

[26] J. Huang and R. . Crookes, “Assessment of simulated biogas as a fuel for the spark ignition engine," Fuel, vol. 77, no. 15, pp. 1793-1801, Dec. 1998, doi: 10.1016/S0016-2361(98)00114-8.

[27] W. D. Hsieh, R. H. Chen, T. L. Wu, and T. H. Lin, "Engine performance and pollutant emission of an SI engine using ethanolgasoline blended fuels," Atmos. Environ., vol. 36, no. 3, pp. 403-410, 2002, doi: 10.1016/S1352-2310(01)00508-8.

[28] C. Wang, A. Janssen, A. Prakash, R. Cracknell, and H. Xu, "Splash blended ethanol in a spark ignition engine - Effect of RON, octane sensitivity and charge cooling," Fuel, vol. 196, pp. 21-31, 2017, doi: 10.1016/j.fuel.2017.01.075.

[29] L. Chen, R. Stone, and D. Richardson, "A study of mixture preparation and PM emissions using a direct injection engine fuelled with stoichiometric gasoline/ethanol blends," Fuel, vol. 96, pp. 120-130, Jun. 2012, doi: 10.1016/j.fuel.2011.12.070.

[30] G. Najafi et al., "SVM and ANFIS for prediction of performance and exhaust emissions of a SI engine with gasoline-ethanol blended fuels," Appl. Therm. Eng., vol. 95, pp. 186-203, 2016, doi: 10.1016/j.applthermaleng.2015.11.009.

[31] A. E. Elik, H. Aydoan, and M. Acarolu, "Determining the performance, emission and combustion properties of camelina biodiesel blends," Energy Convers. Manag., vol. 96, pp. 47-57, 2015, doi: 10.1016/j.enconman.2015.02.024.

[32] P. Iodice, G. Langella, and A. Amoresano, "Ethanol in gasoline fuel blends: Effect on fuel consumption and engine out emissions of SI engines in cold operating conditions," Appl. Therm. Eng., vol. 130, pp. 1081-1089, 2018, doi: 10.1016/j.applthermaleng.2017.11.090.

[33] C. Park et al., "Performance and exhaust emission characteristics of a spark ignition engine using ethanol and ethanol-reformed gas," Fuel, vol. 89, no. 8, pp. 2118-2125, Aug. 2010, doi: 10.1016/j.fuel.2010.03.018.

[34] J. B. Heywood, Internal combustion engine. McGraw-Hill, Inc, 1988.

[35] S. Wang, C. Ji, B. Zhang, and X. Liu, "Realising the part load control of a hydrogen-blended gasoline engine at the wide open throttle condition," Int. J. Hydrogen Energy, vol. 39, no. 14, pp. 7428-7436, May 2014, doi: 10.1016/j.ijhydene.2014.03.024.

[36] D. Jesu Godwin et al., "Effect of hydroxyl (OH) group position in alcohol on performance, emission and combustion characteristics of SI engine," Energy Convers. Manag., vol. 189, no. November 2018, pp. 195-201, 2019, doi: 10.1016/j.enconman.2019.03.063.

[37] P. M. Shameer and K. Ramesh, "Experimental evaluation on performance, combustion behavior and influence of in-cylinder temperature on NOx emission in a DI diesel engine using thermal imager for various alternate fuel blends," Energy, vol. 118, pp. 1334-1344, 2017, doi: 10.1016/j.energy.2016.11.017.

[38] A. O. Hasan et al., "Impact of changing combustion chamber geometry on emissions, and combustion characteristics of a single cylinder SI (spark ignition) engine fueled with ethanol/gasoline blends," Fuel, vol. 231, no. May, pp. 197-203, 2018, doi: 10.1016/j.fuel.2018.05.045.

[39] A. Cairns, H. Zhao, A. Todd, and P. Aleiferis, "A study of mechanical variable valve operation with gasoline-alcohol fuels in a spark ignition engine,” Fuel, vol. 106, pp. 802-813, Apr. 2013, doi: 10.1016/j.fuel.2012.10.041. 
[40] H. Sharudin, N. R. Abdullah, G. Najafi, R. Mamat, and H. H. Masjuki, "Investigation of the effects of iso-butanol additives on spark ignition engine fuelled with methanol-gasoline blends," Appl. Therm. Eng., vol. 114, pp. 593-600, 2017, doi: 10.1016/j.applthermaleng.2016.12.017.

[41] M. Canakci, A. N. Ozsezen, E. Alptekin, and M. Eyidogan, "Impact of alcohol-gasoline fuel blends on the exhaust emission of an SI engine," Renew. Energy, vol. 52, pp. 111-117, Apr. 2013, doi: 10.1016/j.renene.2012.09.062.

[42] C. Sayin, "Engine performance and exhaust gas emissions of methanol and ethanol-diesel blends," Fuel, vol. 89, no. 11, pp. 3410-3415, 2010, doi: 10.1016/j.fuel.2010.02.017.

[43] V. R. Roso et al., "Effects of mixture enleanment in combustion and emission parameters using a flex-fuel engine with ethanol and gasoline," Appl. Therm. Eng., vol. 153, pp. 463-472, 2019, doi: 10.1016/j.applthermaleng.2019.03.012.

[44] A. Elfasakhany, "Exhaust emissions and performance of ternary iso-butanol-bio-methanol-gasoline and n-butanol-bioethanol-gasoline fuel blends in spark-ignition engines: Assessment and comparison," Energy, vol. 158, pp. 830-844, 2018, doi: 10.1016/j.energy.2018.05.120.

[45] B. M. Masum, et al., "Effect of alcohol-gasoline blends optimisation on fuel properties, performance and emissions of a SI engine,” J. Clean. Prod., vol. 86, pp. 230-237, Jan. 2015, doi: 10.1016/j.jclepro.2014.08.032. 